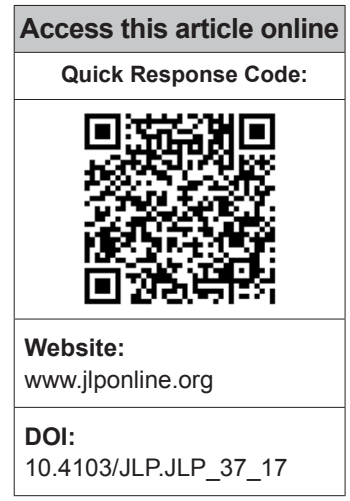

Department of Microbiology, Advance Research Laboratory, ${ }^{1}$ Department of Medicine, SMS Medical College, Jaipur, Rajasthan, India

Address for correspondence: Dr. Bharti Malhotra,

Department of

Microbiology and

Immunology, Advance

Research Laboratory,

SMS Medical College, Jaipur, Rajasthan, India.

E-mail: drbhartimalhotra@ gmail.com

Submission: 08-05-2017 Accepted: 01-08-2017

\title{
Cluster of differentiation 4+ T-cell counts and human immunodeficiency virus-1 viral load in patients coinfected with hepatitis B virus and hepatitis C virus
}

Sakshee Gupta, Bharti Malhotra, Jitendra Kumar Tiwari, Prabhu Dayal Khandelwal', Rakesh Kumar Maheshwari

Abstract:

BACKGROUND: Coinfections of human immunodeficiency virus (HIV) with hepatitis viruses may affect the progress of disease and response to therapy.

OBJECTIVES: To study the incidence of hepatitis B virus (HBV) and hepatitis C virus (HCV) coinfections in HIV-positive patients and their influence on HIV-1 viral load and cluster of differentiation 4+ (CD4+) T-cell counts.

MATERIALS AND METHODS: This pilot study was done on 179 HIV-positive patients attending antiretroviral therapy (ART) centre. Their blood samples were tested for HIV-1 viral load, CD4+ T-cell counts, hepatitis B surface antigen, anti-HCV antibodies, HBV DNA and HCV RNA polymerase chain reaction.

RESULTS: Among the 179 patients, 7.82\% (14/179) were coinfected with HBV and 4.46\% (8/179) with HCV. Median CD4+ T-cell count of HIV monoinfected patients was $200 \mathrm{cells} / \mu \mathrm{l}$ and viral load was $1.67 \log _{10}$ copies/ $\mu$ l. Median CD4+ T-cell counts of 193 cells $/ \mu$ for HBV $(P=0.230)$ and 197 cells $/ \mu l$ for $\operatorname{HCV}(P=0.610)$ coinfected patients were similar to that of HIV monoinfected patients. Viral load was higher in both HBV and HCV infected patients but statistically significant only for HCV $(P=0.017)$. Increase in CD4+ T-cell counts and decrease in HIV-1 viral load in coinfected patients on 2 years of ART were lower than that in HIV monoinfected patients.

CONCLUSION: HBV/HCV coinfected HIV patients had similar CD4+ T-cell counts as in HIV monoinfected patients, higher HIV viral load both in chemo-naive patients and in those on ART as compared to HIV monoinfected patients. However, this study needs to be done on a large scale to assess the impact of coinfection on CD4 count and HIV viral load with proper follow-up of patients every 6 months till at least 2 years.

Key words:

Cluster of differentiation 4+ T-cell count, coinfection, hepatitis B virus, hepatitis C virus, human immunodeficiency virus-1 viral load

\section{Introduction}

Tn India, approximately 21.17 lakhs (17.11 lakhs-26.49 lakhs) people are living with human immunodeficiency virus (HIV) as estimated in 2015 in a population of more than 1.3 billion. ${ }^{[1]}$

This is an open access article distributed under the terms of the Creative Commons Attribution-NonCommercial-ShareAlike 3.0 License, which allows others to remix, tweak, and build upon the work non-commercially, as long as the author is credited and the new creations are licensed under the identical terms.

For reprints contact: reprints@medknow.com
In the United States, among the HIV-positive patients, about $25 \%$ were coinfected with hepatitis $\mathrm{C}$ virus ( $\mathrm{HCV}$ ) and about $10 \%$ were coinfected with hepatitis B virus (HBV). ${ }^{[2]}$ $\mathrm{HBV}$ endemicity in India is considered at an intermediate level with over 40 million HBV carriers. ${ }^{[3]}$ As per the World Health

\footnotetext{
How to cite this article: Gupta S, Malhotra B, Tiwari JK, Khandelwal PD, Maheshwari RK. Cluster of differentiation 4+ T-cell counts and human immunodeficiency virus-1 viral load in patients coinfected with hepatitis $B$ virus and hepatitis C virus. J Lab Physicians 2018;10:162-7.
} 
Organization (WHO), India has 6-12 million people infected with $\mathrm{HCV}$.

It is important to understand the impact of HBV and $\mathrm{HCV}$ coinfections on HIV viral load and cluster of differentiation 4 (CD4+) T-cell count in chemo-naive patients and in those on anti-retroviral treatment (ART). It has been shown in various studies that, following highly active ART (HAART), hepatitis-related liver disease mortality has significantly increased, and is the most common cause of non-AIDS-related deaths among HIV-positive patients. ${ }^{[4]}$

Although various authors have evaluated the short-term response to ART on $\mathrm{HIV} / \mathrm{HBV}$ and $\mathrm{HIV} / \mathrm{HCV}$ coinfected individuals, the impact of HBV and HCV on HIV treatment outcomes is not clear due to variable reports. ${ }^{[5-9]}$

For proper management of HIV-positive patients, it is important to understand the impact of coinfection with HBV and HCV in terms of viral load and CD4+ T-lymphocyte counts in these patients versus the HIV-positive patients not having coinfection which is particularly important in South-East Asia region as it bears an estimated burden of 100 million chronic HBV and 50 million chronic HCV infections. ${ }^{[3]}$

Thus, the present study was undertaken with the objective to evaluate the impact of coinfection with HBV and HCV on HIV-1 viral load and CD4+ T-cell count among HIV-infected patients who are chemo-naive and on ART at a tertiary care center in western region of India.

\section{Materials and Methods}

One hundred and seventy-nine HIV-seropositive patients attending ART center, a tertiary care hospital, were enrolled in this pilot study carried out during 2013 (1 year). HIV-positive patients who had coinfections other than HBV or HCV such as Mycobacterium tuberculosis, candidiasis, and other fungal infections; viral infections such as herpes and cytomegalovirus; and other comorbidities were excluded from the present study. Detailed clinical history including signs, symptoms, list of medications, past history of opportunistic infections (OIs), and relevant laboratory reports and demographic characteristics of all known HIV-positive patients included in the study were recorded. Ethical clearance was obtained from institutional ethics committee and consent forms were filled by all patients.

CD4+ T-cell counts were estimated by BD FACS Calibur flow cytometer (Becton and Dickinson, San Jose, USA). HIV-1 viral load estimation was done using COBAS ${ }^{\circledR}$ TaqMan $^{\circledR} 48$ analyzer using COBAS ${ }^{\circledR}$ TaqMan $^{\circledR}$ HIV-1 kit (Roche Diagnostics, Mannheim, Germany), which has a linear range of detection of 47 copies $/ \mathrm{ml}$ to $10^{7}$ copies $/ \mathrm{ml}$. Hepatitis B surface antigen (HBsAg) and anti-HCV antibodies were tested with a third-generation enzyme immunoassay (EIA) (J Mitra and Co Pvt., Ltd, New Delhi, India). Patients negative for HBsAg and anti-HCV antibodies by EIA were tested for the presence of HBV DNA/HCV RNA by a qualitative polymerase chain reaction (PCR) using primer sequences (5'-TTT CAC CTC TGC CTA ATC ATC TC-3' [sense primer] and 5'-TTT ACC TCT GCC TAA TCA TCT C-3' [anti-sense primer $]^{[10]}$ for HBV DNA and outer primers $5^{\prime}-\mathrm{CTG}$ TGA GGA ACT ACT GCT T-3' [sense primer] and 5'-GGC TCA TGG TGC ACG GTC TAC GAG ACC TCC GG-3' [anti-sense primer]; inner primers-5'-TTC ACG CAG AAA GCG TCT AG-3' [sense primer] and 5'-CAC TCG CAA GCA CCC TAT-3' [anti-sense primer] for HCV RNA). ${ }^{[11]}$ Amplification and detection were done using conventional PCR. ${ }^{[10,11]}$ Continuous variables were expressed as median (including interquartile range) and categorical variables as the number of cases (percentage). For measurement data, normal distribution of the measurement data was tested first. $t$-test (normal distribution) and Wilcoxon test were applied (nonnormal distribution) to analyze the differences among different groups of patients, i.e., CD4+ T-cell counts and HIV-1 viral load between HIV monoinfected and HIV-HCV or HIV-HBV coinfected patients. Tests were two sided, and $P<0.05$ was considered statistically significant. Analyses were performed using SPSS for Windows version 17.0 (SPSS Inc., Chicago, IL, USA).

\section{Results}

Out of the 179 patients, $14(7.82 \%)$ were detected positive for HBV ( 5 by EIA and 9 by PCR) and 8 (4.46\%) were detected positive for HCV ( 2 by EIA and 6 by PCR). Male:female ratio was 2.07:1 in HIV monoinfected group, 1.8:1 in HBV coinfected group, and 1.6:1 in HCV coinfected group. Median age of the patients in these three groups was 18, 35.5, and 29 years, respectively. In HIV monoinfected/HBV/HCV coinfected groups, $64.33 \%, 57.14 \%$, and $60 \%$ of patients were confined to the WHO clinical stage I/II and $35.67 \%, 42.86 \%$, and $30 \%$ to stage III/IV.

Overall, median CD4+ T-cell counts in HIV mono- and co-infected patients were similar. However, viral load of HIV-HBV and HIV-HCV coinfected patients was higher but statistically significant only for HCV coinfection $(P=0.017)$ [Table 1].

Median CD4+ T-cell counts were lower in chemo-naive HIV monoinfected patients and were higher in patients after 2 years of treatment $(P=0.133)$. Viral load of patients was significantly lower in patients after 2 years of ART as compared to chemo-naive patients $(P=0.032)$ [Table 2]. 
Table 1: Demographic, clinical and laboratory variables of human immunodeficiency virus and coinfected patients

\begin{tabular}{|c|c|c|c|c|}
\hline & HIV monoinfection (Group 1) & HBV coinfection (Group 2) & HCV coinfection (Group 3) & $\boldsymbol{P}$ \\
\hline Number of patients (\%) & $157(87.7)$ & $14(7.82)$ & $8(4.46)$ & \\
\hline \multicolumn{5}{|l|}{ Sex } \\
\hline Male & 106 & 9 & 5 & \\
\hline Female & 51 & 5 & 3 & \\
\hline Age; median (range) & $18(1-60)$ & $35.5(4-50)$ & $29(6-35)$ & \\
\hline $\begin{array}{l}\text { CD4+ T-cell counts; median } \\
\text { cells/ } \mu \text { (range) }\end{array}$ & $200(10-1420)$ & $193(23-432)$ & $197(25-798)$ & $\begin{array}{l}P_{12}=0.230 \\
P_{13}=0.610\end{array}$ \\
\hline $\begin{array}{l}\text { VLs; median log } 10 \text { copies/ml } \\
\text { (range) }\end{array}$ & $1.67(0-7)$ & $3.81(0-5.33)$ & $3.98(1.98-5.50)$ & $\begin{array}{l}P_{12}=0.078 \\
P_{13}=0.017\end{array}$ \\
\hline \multicolumn{5}{|l|}{ WHO stage } \\
\hline Clinical stage $\mathrm{I} / \mathrm{II}$ & 32 & 8 & 3 & \\
\hline Clinical stage III/IV & 10 & 6 & 5 & \\
\hline
\end{tabular}

CD4+ = Cluster of differentiation 4+, WHO = World Health Organization, HIV = Human immunodeficiency virus, $\mathrm{HBV}=\mathrm{Hepatitis} \mathrm{B} \mathrm{virus,} \mathrm{HCV}=\mathrm{Hepatitis} \mathrm{C}$ virus, VLs $=$ Viral loads

Table 2: Cluster of differentiation 4+T-cell counts and plasma viral load in human immunodeficiency virus monoinfected/coinfected patients with and without anti-retroviral treatment

\begin{tabular}{|c|c|c|c|c|}
\hline Coinfections & CD4+T-cell count median (range) cells/ $\mu \mathrm{l}$ & $\boldsymbol{P}$ & VLs median (range) log10 copies/ml & $\boldsymbol{P}$ \\
\hline $\begin{array}{l}\text { Group 1: HIV monoinfected } \\
\text { patients }(n=157)\end{array}$ & $\begin{array}{l}>2 \text { years on ART: } 247(25-2227) \\
\text { No ART: } 187(10-2152)\end{array}$ & 0.133 & $\begin{array}{l}>2 \text { years on ART: } 1.67(0-6.25) \\
\text { No ART: } 3.79(0-7)\end{array}$ & 0.032 \\
\hline $\begin{array}{l}\text { Group 2: HBV coinfection } \\
(n=14)\end{array}$ & $\begin{array}{l}>2 \text { years on ART: } 203(26-717) \\
\text { No ART: } 57(23-120)\end{array}$ & 0.103 & $\begin{array}{l}>2 \text { years on ART: } 3.36(0-5.83) \\
\text { No ART: } 3.39 \text { (3.04-5.32) }\end{array}$ & 0.810 \\
\hline Group 3: HCV coinfection $(n=8)$ & $\begin{array}{l}>2 \text { years on ART: } 412(25-798) \\
\text { No ART: } 224(37-410)\end{array}$ & 0.704 & $\begin{array}{l}>2 \text { years on ART: } 3.13(0-3.43) \\
\text { No ART: } 4.54(3.98-4.79)\end{array}$ & 0.413 \\
\hline$P$ value & & & & \\
\hline For HBV & $\begin{array}{l}\text { CD4 } P_{12}:>2 \text { years ART } \\
\text { CD4 } P_{12}: \text { No ART }\end{array}$ & $\begin{array}{l}0.325 \\
0.225\end{array}$ & $\begin{array}{l}\text { VLs P12: >2 years ART } \\
\text { VLs P12: No ART }\end{array}$ & $\begin{array}{l}0.776 \\
0.029\end{array}$ \\
\hline For HCV & $\begin{array}{l}\text { CD4 } P_{13}:>2 \text { years ART } \\
\text { CD4 } P_{13}: \text { No ART }\end{array}$ & $\begin{array}{l}0.916 \\
0.743\end{array}$ & $\begin{array}{l}\text { VLs P13: >2 years ART } \\
\text { VLs P13: No ART }\end{array}$ & $\begin{array}{l}0.019 \\
0.024\end{array}$ \\
\hline
\end{tabular}

${ }^{*}$ For HIV monoinfected patients - $>2$ years on ART $(n=67)$, No ART $(n=48)$; For HBV - >2 years on ART $(n=10)$, No ART $(n=4)$; For HCV - >2 years on ART $(n=6)$, No ART $(n=2) \cdot{ }^{[4,13]} \mathrm{HIV}=$ Human immunodeficiency virus, HBV $=$ Hepatitis B virus, HCV $=$ Hepatitis $\mathrm{C}$ virus, CD4+ = Cluster of differentiation 4+, $\ddagger(42)$ HIV monoinfected patients out of 157 were not included in this table as they fell in treatment duration from 6 months - 2 years. †ART $=$ Anti-retroviral treatment, VLs $=$ Viral loads

No significant difference was observed in CD4+ T-cell counts between both groups (HIV monoinfected vs. coinfected) of patients with and without ART. HIV-1 viral load in HBV and HCV coinfected chemo-naive patients was significantly higher than those of HIV monoinfected chemo-naive patients (for HBV, $P=0.029$; $\mathrm{HCV}, P=0.024)$. Patients on ART for more than 2 years also had higher HIV-1 viral load values in coinfected groups, but it was significant only for $\mathrm{HCV}$ coinfected group (for $\mathrm{HBV}, P=0.776 ; \mathrm{HCV}, P=0.019$ ) [Table 2].

Out of 14 HIV-HBV coinfected patients, chemo-naive patients were associated with lower median CD4+ T-cell counts as compared to patients on more than 2 years of ART $(P=0.103)$. Furthermore, the median HIV-1 viral load was higher in chemo-naive patients when these two groups were compared $(P=0.810)$ [Table 2].

Out of eight HIV-HCV infected patients, chemo-naive patients were associated with lower median CD4+ T-cell counts as compared to patients on more than 2 years on ART $(P=0.704)$. The median HIV load was higher in chemo-naive patients as compared to patients on 2 years of ART $(P=0.413)$ [Table 2]. However, both of them were statistically insignificant.

\section{Discussion}

Variable coinfection rates have been reported for HBV and HCV in HIV patients around the world, depending on the geographic area under study, risk groups, and the type of exposure involved. In the present study, $7.82 \%$ and $4.46 \%$ of HIV-infected patients were coinfected with HBV and HCV, respectively. Similar observations, i.e., HBV $6 \%-6.4 \%$ and $\mathrm{HCV} 2.1 \%-4.8 \%{ }^{[1,12]}$ have been reported from Chennai and 15\% HBV and $8.3 \% \mathrm{HCV}$ coinfection from Hyderabad. ${ }^{[13]}$ Studies from North India have reported lower percentage of coinfection; Delhi reported 3.6\%-7.28\% HBV and $0.2 \%-2.2 \% \mathrm{HCV},{ }^{[14,15]}$ Agra reported 9\% HBV 
coinfections, ${ }^{[16]}$ Kolkata reported $11.3 \%$ HBV and 1.9\% $\mathrm{HCV}$ coinfection, ${ }^{[17]}$ and Chhattisgarh reported $6 \% \mathrm{HBV}$ and $2 \% \mathrm{HCV},{ }^{[18]}$ whereas very high prevalence rates have been reported from the USA, i.e., $30 \%-50 \%$, ${ }^{[19]}$ and $8.5 \%$ HIV-HBV and 2.8\% HIV-HCV from western region of Saudi Arabia. ${ }^{20]}$

In this study, we observed that CD4+ T-cell counts did not differ between HIV monoinfected and $\mathrm{HBV} / \mathrm{HCV}$ coinfected patients. However, HIV-1 viral load was found to be higher in HBV and HCV coinfected group as compared to HIV monoinfected patients which was statistically significant for HCV coinfection $(P=0.078$; $P=0.017)$. Similar findings were reported from Gondar, Africa, where mean CD4+ T-cell counts were 288 cells $/ \mathrm{mm}^{3}$ in HIV monoinfection and slightly lower count (about $14-38$ cells $/ \mathrm{mm}^{3}$ lower) in HIV-HBV and HIV-HCV coinfected patients but not statistically significant. ${ }^{[21]}$ On the contrary, previous studies from Jaipur and Chandigarh observed that HIV / HBV coinfected patients had significantly lower CD4 T-cell counts than the monoinfected group $(P=0.03) .^{[22,23]}$ An American study also concluded that, compared with patients without coinfection, coinfected patients showed impaired CD4+ T-cell recovery, despite similar virological response to HIV-1 therapy. ${ }^{[8]}$ Greivensen from Belgium also reported a lesser CD4 increase among $\mathrm{HCV} / \mathrm{HBV}$ coinfected patients as compared to HIV monoinfected patients, but it was statistically significant only for HBV coinfection $(P=0.001) \cdot{ }^{[24]}$

These variations may be due to differences in local epidemiology, prevalent genotypes of $\mathrm{HIV} / \mathrm{HBV} / \mathrm{HCV}$, follow-up time, the viral loads of HBV and HCV, and whether patients were receiving any antiviral agents for $\mathrm{HBV} / \mathrm{HCV}$ infection, population characteristics (in particular, the relative importance of intravenous drug users), etc. ${ }^{[2]}$ Many a times, HIV patients are not aware of their HBV/HCV infection status; as a result, these infections remain unattended. In patients with HBV and HCV coinfections, HIV viral load may be a better marker to predict response to ART as increase in CD4+ T-cell counts may be similar to HIV monoinfected patients [Table 1].

In our study, in HBV and HCV coinfected groups as well as in HIV monoinfected patients, CD4+ T-cell counts were below 500 cells/ $\mu 1$ despite remaining on ART for 2 years.

When HIV monoinfected group was compared to coinfected ones in terms of HIV-1 viral load in patients with and without ART, significant differences were obtained for chemo-naive patients only. Viral load of HIV monoinfected chemo-naive patients was lower than HCV coinfected $(P=0.024)$ but higher than HBV coinfected patients $(P=0.029)$. HIV-1 viral load of patients on ART for more than 2 years was higher in coinfected groups as compared to HIV monoinfected patients, but statistically significant only for HCV coinfected group $(P=0.019)$. HIV promotes hepatic fibrogenesis by production of reactive oxygen by hepatocytes through a Kappa-dependent pathway, this effect is enhanced in the presence of $\mathrm{HCV} \cdot{ }^{[25]}$ Recent studies from Manipur, India, ${ }^{[6]}$ Asia, ${ }^{[26]}$ Switzerland, ${ }^{[27]}$ and Australia ${ }^{[28]}$ have postulated that patients coinfected with $\mathrm{HIV} / \mathrm{HBV} /$ HCV appear to have a poorer response to HAART in terms of CD4+ T-cell count changes. A Chinese study also inferred similar results in HIV/HBV coinfected individuals at 48 months post-ART both in terms of CD4+ T-cell count and HIV-1 RNA suppression. ${ }^{[29]}$ Studies from other parts of the world have reported variable results regarding CD4+ T-cell recovery and HIV-1 viral load suppression after ART. Many studies from India and around the world have reported that $\mathrm{HBV} / \mathrm{HCV}$ coinfection did not affect CD4+ T-cell counts and HIV-1 viral load suppression after ART. ${ }^{[5-7,9]}$ It has been hypothesized that splenic sequestration of lymphocytes due to HBV-related hepatic fibrosis may be responsible for lower CD4+ T-cell recovery. ${ }^{[30]}$ Many underlying comorbid conditions, other OIs, small sample size, and lack of compliance/adherence may affect these results.

Some patients enrolled in HIV care and prescribed ART do not attain an adequate virologic and immunologic response due to inconsistent retention in care, poor adherence, unfavorable pharmacokinetics, or unexplained biologic factors. ${ }^{[31]}$ Failure of HIV-1 viral load to reach undetectable levels in patients on ART leads to faster disease progression.

To summarize our key findings, the primary outcome of our pilot study was that CD4+ T-cell counts were similar in coinfected patients versus monoinfected patients in both chemo-naïve patients and those on ART, which is controversial as compared to some of the other studies. HIV-1 viral load in HBV and HCV coinfection was significantly higher than those of HIV monoinfection in both chemo-naive patients and those on ART (HBV patients not significant statistically). Secondary outcome observed was that response to ART after 2 years in HIV monoinfected patients was not optimum, stress should be laid on patient compliance and adherence to ART.

There were many limitations in our study: the study design should have been better planned, prospective study is needed with larger sample size comparing CD4+ T-cell count and viral load in monoinfected and coinfected patients, follow-up of patients should have been done and data should have been collected before ART, at 6 months, 1 and 2 years of ART, and should have 
been analyzed accordingly. Test should have been done to identify occult $\mathrm{HBV}$ infection, correlate $\mathrm{HBV}$ and $\mathrm{HCV}$ viral load and genotypes with response to ART, correlate response with therapeutic drugs given, and test for other OIs too. Strength of our study was HIV viral load testing which has been done by only limited authors and we observed that HIV viral load may be better marker to evaluate response to ART in coinfection cases as only the CD4+ T-cell response may not be able to assess the same.

The National Aids Control Organization guidelines recommend the initiation of ART irrespective of CD4+ T-cell count values in HIV/HBV coinfected patients with documented evidence of chronic active hepatitis, ${ }^{[1]}$ but there is no guideline for active screening of HIV patients for HBV and HCV coinfection and no additional care is taken in coinfected persons as regard to ART. There is a need to change this and active screening for HBV-HCV coinfection should be started as suggested by the CDC guidelines ${ }^{[2]}$ and give aggressive combination therapy to treat HIV and coinfection. Treatment algorithms need to be evaluated planning right combination of drugs effective for HIV and $\mathrm{HBV} / \mathrm{HCV}$ in case of coinfections to get optimal response. HBV vaccination needs to be implemented. Though there are many constraints such as cost, access to treatment, and laboratory investigations, simplified treatment and monitoring strategies need to be developed for resource-limited countries like ours.

Future prospective studies need to be planned to evaluate the extent and evolution of liver disease in coinfected individuals, effect of hepatitis treatment and ART on liver disease and the associated mortality, identify treatment algorithms for optimal care in HIV, $\mathrm{HBV} / \mathrm{HCV}$ coinfection, associated risk factors, and the role of various genotypes and viral load of each virus. Effect of early initiation of ART and antiviral therapy for $\mathrm{HBV} / \mathrm{HCV}$ should also be explored. Moreover, studies on the role of psychosocial aspects on prognosis and treatment outcome and other host factors such as compliance should also be taken into account when evaluating the impact of coinfection.

\section{Conclusion}

HIV-positive patients with HBV and HCV coinfections had lower CD4+ T-cell counts and higher viral loads in both chemo-naive and in patients on ART. Viral load can be a more sensitive marker to monitor response to ART. However, large-scale studies are needed. Screening for HBV and HCV in all HIV-positive patients is essential for timely detection and treatment of coinfection. Other factors such as comorbidities, individual immunological status, adherence, and relapse should also be monitored.

\section{Acknowledgment}

We thank all patients and technical staff in Advance Research Laboratory and ART centre, SMS Medical College and Hospital, Jaipur, Rajasthan, India.

\section{Financial support and sponsorship}

This study was financially supported by the Indian Council of Medical research JRF - 2008 (33347) ICMR SRF (33347) and State DST project.

\section{Conflicts of interest}

There are no conflicts of interest.

\section{References}

1. National AIDS Control Organization. Annual Report 2015-16. Available from: http://www.naco.gov.in/sites/default/files/ Annual\%20Report\%202015-16_NACO.pdf. [Last accessed on 2017 Mar 21].

2. Guidelines for the Prevention and Treatment of Opportunistic Infections in HIV-Infected Adults and Adolescents. Recommendations from the Centres for Disease Control and Prevention, the National Institutes of Health, and the HIV Medicine Association of the Infectious Diseases Society of America; March, 2017. Available from: https://www.aidsinfo. nih.gov/contentfiles/lvguidelines/adult_oi.pdf. [Last accessed on 2017 Mar 21].

3. National Centre for Disease Control. Viral hepatitis in India, 2010 to 2013. Newsletter; 2014.p.3. Available from: http://www.ncdc.gov. in/writereaddata/linkimages/NewsLtr0103_20146480274026. pdf.[Last accessed on 2017 Mar 21].

4. Guidelines for Prevention and Management of Common Opportunistic Infections/Malignancies Among HIV-Infected Adult and Adolescent. NACO, Ministry of Health and Family Welfare, Government of India. Available from: http://www. Guidelines\%20for $\% 20$ Prevention $\% 20$ and $\% 20$ Management $\% 20$ of $\% 20$ common $\% 20$ opportunistic\%20infections.pdf. [Last accessed on 2017 Mar 21].

5. Okwuraiwe AP, Audu RA, Salu OB, Onwuamah CK, Amoo OS, Ige FA, et al. Immunological and virological response to haart in HIV-1 patients co-infected with hepatitis B and C viruses. West Afr J Med 2012;31:124-8.

6. Rao A, Singh NB, Ninsheng R, Singh TB. Clinical profile and response to first-line anti-retroviral therapy in Human Immunodeficiency Virus infected patients in Manipur. Int J Med Dent Sci 2016;5:970-7.

7. Basso M, Franzetti M, Scaggiante R, Sattin A, Mengoli C, Cruciani $\mathrm{M}$, et al. HCV RNA viral load is independent from CD4 cell count and plasma HIV RNA viral load in immunocompetent HIV-HCV co-infected patients: A 3-years follow-up study. AIDS Res Ther 2014;11:21.

8. Anderson JP, Horsburgh CR Jr., Williams PL, Tchetgen Tchetgen EJ, Nunes D, Cotton D, et al. CD4 recovery on antiretroviral therapy is associated with decreased progression to liver disease among hepatitis $C$ virus-infected injecting drug users. Open Forum Infect Dis 2015;2:ofv019.

9. Sarkar J, Saha D, Bandyopadhyay B, Saha B, Kedia D, Guha Mazumder DN, et al. Baseline characteristics of HIV \& amp; hepatitis B virus (HIV/HBV) co-infected patients from Kolkata, India. Indian J Med Res 2016;143:636-42.

10. Zhang Q, Wu G, Richards E, Jia S, Zeng C. Universal primers for HBV genome DNA amplification across subtypes: A case study for designing more effective viral primers. Virol J 2007;4:92.

11. Asim M, Singla R, Gupta RK, Kar P. Clinical \& amp; molecular 
characterization of human TT virus in different liver diseases. Indian J Med Res 2010;131:545-54.

12. Padmapriyadarsini C, Chandrabose J, Victor L, Hanna LE, Arunkumar N, Swaminathan S, et al. Hepatitis B or hepatitis C co-infection in individuals infected with human immunodeficiency virus and effect of anti-tuberculosis drugs on liver function. J Postgrad Med 2006;52:92-6.

13. Chandra N, Joshi N, Raju YS, Kumar A, Teja VD. Hepatitis B and/or C co-infection in HIV infected patients: A study in a tertiary care centre from South India. Indian J Med Res 2013;138:950-4.

14. Gupta S, Singh S. Hepatitis B and C virus co-infections in human immunodeficiency virus positive North Indian patients. World J Gastroenterol 2006;12:6879-83.

15. Sharma A, Halim J, Jaggi T, Mishra B, Thakur A, Dogra V, et al. Time trends of seroepidemiology of hepatitis $C$ virus and hepatitis $B$ virus coinfection in human immunodeficiency virus-infected patients in a super specialty hospital in New Delhi, India: 2012-2014. Indian J Sex Transm Dis 2016;37:33-7.

16. Hussain T, Kulshreshtha KK, Sinha S, Yadav VS, Katoch VM. HIV, $\mathrm{HBV}, \mathrm{HCV}$, and syphilis co-infections among patients attending the STD clinics of district hospitals in Northern India. Int J Infect Dis 2006;10:358-63.

17. Saha D, Pal A, Biswas A, Panigrahi R, Sarkar N, Sarkar J, et al. Characterization of treatment-naive HIV/HBV co-infected patients attending ART clinic of a tertiary healthcare centre in Eastern India. PLoS One 2013;8:e73613.

18. KhunteP, Khare RL, BeckP, KumarS. Prevalence of hepatitis B virus and hepatitis $C$ virus co-infection in human immunodeficiency virus positive patients: A study from tribal area of central India. Int J Res Med Sci 2015;3:2311-5.

19. Tien PC, Veterans Affairs Hepatitis C Resource Center Program. National Hepatitis C Program Office. Management and treatment of hepatitis $\mathrm{C}$ virus infection in HIV-infected adults: Recommendations from the Veterans Affairs Hepatitis C Resource Center Program and National Hepatitis C Program Office. Am J Gastroenterol 2005;100:2338-54.

20 Al-Mughales JA. Co-infection assessment in HBV, HCV, and HIV patients in Western Saudi Arabia. J Med Virol 2016;88:1545-51.

21. Wondimeneh Y, Alem M, Asfaw F, Belyhun Y. HBV and HCV seroprevalence and their correlation with CD4 cells and liver enzymes among HIV positive individuals at university of Gondar teaching hospital, Northwest Ethiopia. Virol J 2013;10:171.

22. Hooja S, Singhal A, Bachhiwal R, Yadav R, Vyas N. Hepatitis $B$ virus seroprevalence and its correlation with CD4 cells and liver enzymes among human immunodeficiency virus positive individuals at a tertiary care hospital in North-West India. Int J Appl Basic Med Res 2015;5:36-40.

23. KotmireS, Gupta I, Ganguly NK, Koicha M. Study of T-lymphocyte subpopulation in HBsAg-positive pregnant women. Acta Virol 1993;37:459-65.

24. Griensven JV, Phirum L, Choun K, Thai S, De Weggheleire A, Lynen L. Hepatitis B and C co-Infection among HIV-Infected adults while on antiretroviral treatment: Long-term survival, $\mathrm{CD} 4+\mathrm{T}$ cell count recovery and antiretroviral toxicity in Cambodia. Plos One 2014;9:e88552.

25. Karageorgopoulos DE, Allen J, Bhagani S. Hepatitis C in human immunodeficiency virus co-infected individuals: Is this still a "special population"? World J Hepatol 2015; 28; 7: 936-52.

26. Chen M, Wong WW, Law MG, Kiertiburanakul S, Yunihastuti E, Merati TP, et al. Hepatitis B and C co-infection in HIV patients from the TREAT Asia HIV observational database: Analysis of risk factors and survival. PLoS One 2016;11:e0150512.

27. Greub G, Ledergerber B, Battegay M, Grob P, Perrin L, Furrer H, et al. Clinical progression, survival, and immune recovery during antiretroviral therapy in patients with HIV- 1 and hepatitis $C$ virus coinfection: The Swiss HIV cohort study. Lancet 2000;356:1800-5.

28. Lincoln D, Petoumenos K, Dore GJ, Australian HIV Observational Database. HIV/HBV and HIV/HCV coinfection, and outcomes following highly active antiretroviral therapy. HIV Med 2003;4:241-9.

29. Yang R, Gui X, Xiong Y, Gao SC, Yan Y. Impact of hepatitis B virus infection on HIV response to antiretroviral therapy in a Chinese antiretroviral therapy center. Int J Infect Dis 2014;28:29-34.

30. Wandeler G, Gsponer T, Bihl F, Bernasconi E, Cavassini M, Kovari $\mathrm{H}$, et al. Hepatitis $\mathrm{B}$ virus infection is associated with impaired immunological recovery during antiretroviral therapy in the Swiss HIV cohort study. J Infect Dis 2013;208:1454-8.

31. Buchacz K, Baker RK, Palella FJ Jr., Chmiel JS, Lichtenstein KA, Novak RM, et al. AIDS-defining opportunistic illnesses in US patients, 1994-2007: A cohort study. AIDS 2010;24:1549-59. 